\title{
AN EVALUATION OF THE NUTRITIONAL STATUS OF ELDERLY WITH THE USE OF THE MNA QUESTIONNAIRE AND DETERMINATION OF FACTORS CONTRIBUTING TO MALNUTRITION. A PILOT STUDY
}

\author{
Matgorzata Kosteckal, Monika Bojanowska
}

${ }^{1}$ University of Life Science, Faculty of Food Science and Biotechnology, Department of Chemistry, Akademicka street 15, 20-950, Lublin, Poland

\begin{abstract}
Background. In the elderly, nutrition significantly influences biological aging and physiological and pathological changes in the body. A balanced diet and physical activity are the key to good physical and mental health.

Objective. The aim of this study was: (1) to perform nutritional screening tests in senior citizens residing in eastern Poland and (2) to evaluate the risk of malnutrition in elderly people who live with their families, seniors who live independently, and residents of nursing homes.

Material and method. The Mini Nutritional Assessment (MNA) screening tool comprising a questionnaire with 22 questions and an abbreviated and survey-adapted version of the questionnaire (KomPAN) were used to investigate eating habits and self-perception of health and nutrition. A total of 398 correctly filled out questionnaires were selected and the resulting data were subjected to statistical analyses in the Statistica 10 program.

Results. The BMI values of most respondents were indicative or malnutrition or risk of malnutrition, regardless of gender (mean BMI $23.88 \mathrm{~kg} / \mathrm{m} 2 \pm 5.08$ ). Most overweight and obese respondents were female $(\mathrm{p}=0.0001)$. The observed decreased BMI values was significantly $(\mathrm{p}=0.0012, \mathrm{rs}=0.6714)$ correlated with lower food intake. Unintentional weight loss greater than $3 \mathrm{~kg}$ was most frequently noted in respondents living in nursing homes and living independently $(\mathrm{p}=0.0021)$. Eating difficulties also considerably influenced the respondents' nutritional status. The respondents' BMI values were significantly correlated $(\mathrm{p}<0.0001)$ with their MNA scores, the average MNA score was 21.0 \pm 4.4 , $(\mathrm{rs}=0.7293)$. Overweight and obese respondents were more likely to consume at least three meals daily $(\mathrm{OR}=1.87 ; 95 \% \mathrm{CI}$ : 1.32-2.06; $\mathrm{p}<0.001)$.

Conclusions. The BMI values and MNA scores of the tested subjects indicate that the majority of the surveyed respondents were malnourished or at risk of malnutrition, regardless of gender. In the present study, the residential environment significantly influenced the patients' nutritional status, in particular in respondents with impaired motor abilities and eating difficulties.
\end{abstract}

Key words: malnutrition, MNA, unintentional weight loss, BMI, elderly people

\section{STRESZCZENIE}

Wprowadzenie. Sposób żywienia w wieku starszym wywiera istotny wpływ na biologiczne starzenie się oraz fizjologiczne i patologiczne zmiany organizmu. Prawidłowe odżywienie jest podstawą utrzymania zdrowia i kondycji fizycznej.

Cel. Celem pracy była 1) przesiewowa ocena stanu odżywienia osób starszych na terenie wschodniej Polski, 2) ocena czynników ryzyka występowania niedożywienia wśród osób mieszkających z rodzinami, samotnie lub w domach pomocy społecznej.

Material i metody. Badanie zostało przeprowadzone za pomocą ankiety opartej na kwestionariuszu Mini Nutritional Assessment (MNA) zawierającej metryczkę i 22 pytania oraz zmodyfikowanego kwestionariusza (KomPAN) do badania zwyczajów żywieniowych i sposobu żywienia. Uzyskano 398 prawidłowo wypełnionych kwestionariuszy, które poddano analizie w programie Statistica 10.

Wyniki. Zdecydowana większość badanych osób starszych bez względu na płeć cechowała się niedożywieniem lub miała ryzyko niedożywienia ocenione na podstawie wartości BMI (BMI średnie 23,88 kg/m2 $\pm 5,08$ ). Wśród osób z nadwagą i otyłością statystycznie częściej występowały kobiety $(\mathrm{p}=0,0001)$. Spadek masy ciała był statystycznie istotnie związany $\mathrm{z}$ ograniczeniem przyjmowania posiłków u badanych $(\mathrm{p}=0,0012)$. Najczęściej niezamierzony spadek masy ciała powyżej $3 \mathrm{~kg}$ odnotowano u osób mieszkających samotnie lub w DPS ( $\mathrm{p}=0,0021)$. Trudności w spożywaniu posiłków miały duży wpływ na stan odżywienia badanych. Zależności pomiędzy wartością BMI, a ilością punktów uzyskanych przez respondentów w teście MNA były istotne statystycznie ( $\mathrm{p}<0,0001)$, wraz ze spadkiem wartości BMI występował spadek ilości punktów uzyskanych w teście MNA. Średnia ilość punktów, którą uzyskali respondenci w teście MNA wyniosła

Corresponding author: Magorzata Kostecka, University of Life Science, Faculty of Food Science and Biotechnology, Department of Chemistry, Akademicka street 15, 20-950, Lublin, Poland, phone number: +48 8144568 46; e-mail: kostecka.malgorzatam@gmail.com

(C) Copyright by the National Institute of Public Health - National Institute of Hygiene 
$21,0 \pm 4,4$. Osoby z nadmierną masą ciała istotnie częściej spożywały co najmniej 3 posiłki dziennie $(\mathrm{OR}=1,87 ; 95 \% \mathrm{CI}$ : $1,32-2,06 ; \mathrm{p}<0,001)$.

Wnioski. Zdecydowana większość badanych osób starszych bez względu na płeć cechowała się niedożywieniem lub miała ryzyko niedożywienia ocenione na podstawie wartości BMI i wyniku testu MNA. W przeprowadzonym badaniu środowisko zamieszkania miało istotny wpływ na stan odżywienia pacjentów, szczególnie w przypadku wystąpienia ograniczeń ruchowych lub zaburzeń w przyjmowaniu pokarmów.

Słowa kluczowe: niedożywienie, $M N A$, niezamierzona utrata masy ciała, BMI, osoby starsze

\section{INTRODUCTION}

The elderly population is growing rapidly around the world and is expected to increase from 739 million in 2009 to 2 billion in 2050 [33]. In the elderly, nutrition significantly influences biological aging and physiological and pathological changes in the body [19]. A balanced diet and physical activity are the key to good physical and mental health. Malnutrition decreases physical ability and quality of life, it prolongs hospitalization and contributes to higher mortality in the senior population $[22,29]$.

The elderly are particularly susceptible to malnutrition due to age-related changes in brain regulation of hunger and satiety, lower compensation for energy intake from food, changes in the gastrointestinal tract (lower metabolic rate) and weakening of the sense of smell and taste. Coexisting chronic diseases, dental problems, depression, impaired mobility or immobilization also contribute to malnutrition [3, 17]. The risk of malnutrition increases significantly in patients with cancer, gastrointestinal, cardiovascular, respiratory and neurological diseases [32].

Malnutrition in the elderly increases the risk of muscular atrophy and muscle weakness, it lowers psychomotor skills and bone mineral density, contributes to the risk of bone fracture, anemia, immune disorders, increases susceptibility to infections, respiratory disorders, water-electrolyte imbalance, orthostatic hypotension, bed sores, wound infections and prolongs healing of postoperative wounds $[1,3,9]$. Nutrition is often correlated with socioeconomic status. Older citizens with low socioeconomic status cannot afford wholesome food products [10]. Environmental factors also play a role in nutrition. Social isolation, loneliness and grieving contribute to malnutrition as well as protein, mineral and vitamin deficiencies [23]. Pharmacological treatment can also decrease appetite, promote nausea and impair intestinal absorption.

In geriatric patients, screening tests are recommended as the first step in diagnosing malnutrition. Simple, low-cost and rapid methods should be used to detect malnutrition in the elderly [12]. According to the European Society for Clinical Nutrition and Metabolism (ESPEN), nutritional status should be diagnosed with standard screening tools such as the Mini Nutrition Assessment (MNA), Nutrition Risk Screening 2002 (NRS) and the Malnutrition
Universal Screening Tool (MUST) [15, 16, 18]. Various screening tools are used in different countries. The Malnutrition Universal Screening Tool is a popular solution in Australia and the United Kingdom [14], whereas the NRS 2002 tool is more widely used in Western Europe [28]. In Poland, the MNA is one of the most popular nutrition screening tools. It involves a questionnaire for evaluating the risk of malnutrition in elderly patients in nursing homes, senior care centers and hospitals as well as in independently living seniors with normal albumin levels and BMI values. The MNA is a highly valuable tool which evaluates both physical and mental health. It accounts for the food intake, weight loss, mobility, psychological stress and acute physical illness in the three months preceding the test. Assessing malnutrition in older people with simple tools can be critical to early diagnosis and intervention. In addition, learning about the risk factors for malnutrition will help direct the attention of medical staff and nutritionists to the most at-risk groups. The obtained results will allow to find out the frequency of the problem and to develop a support strategy for the elderly at risk of malnutrition.

The aim of this study was to perform nutritional screening tests in senior citizens residing in eastern Poland and to evaluate the risk of malnutrition in elderly people who live with their families, seniors who live independently, and residents of nursing homes.

\section{MATERIAL AND METHODS}

\section{Place and period of study}

The study was carried out between March and June 2019 in the Lublin Region in eastern Poland.

\section{Methods}

The Mini Nutritional Assessment (MNA) screening tool comprising a questionnaire with 22 questions and an abbreviated and survey-adapted version of the questionnaire (KomPAN) were used to investigate eating habits and self-perception of health and nutrition. The inclusion criteria were age higher than 65 years, permanent residence in the Lublin Region and absence of mental or neurodegenerative diseases preventing direct contact and completion of the questionnaire. Persons with chronic and terminal illnesses were excluded from the study. The 
participants gave their consent to participate in the study, were informed about its purpose and that the collected data would not make it possible to identify the participants. The questionnaire was filled out independently or with the assistance of a care worker by a total of 546 respondents. Anthropometric measurements were also performed. Participation in the study was voluntary and anonymous, and all respondents gave their consent to participate in the survey.

Four anthropometric assessments were taken by the surveyor while participants wore light clothing and were barefoot: height, weight, calf circumference (CC) and mid-arm circumference (MAC). Height was measured using a mechanical stadiometer; weight was measured with a digital weighing scale. The Body Mass Index was calculated as weight in $\mathrm{kg} /$ (height in $\mathrm{m})^{2}$. Calf circumference was measured on seated participants with an inextensible tape at several locations to find the maximal bare calf circumference. For mid-arm circumference, the participant's forearm was held in horizontal position to locate and mark the mid-distance between the acromial surface of the scapula and the olecranon process of the elbow.

The sum of the MNA score distinguishes between elderly patients with: 1) adequate nutritional status, MNA $\geq 24$; 2) protein-calorie malnutrition, MNA $<17$; 3) risk of malnutrition, MNA between 17 and 23.5. The obtained scores were characterized by $96 \%$ sensitivity, $98 \%$ specificity and $97 \%$ predictive value [16].

\section{Statistical Analysis}

A total of 398 correctly filled out questionnaires were selected, and the resulting data were subjected to mathematical and statistical analyses in the Statistica 10 program. Normality of the distribution of continuous variables was assessed with the ShapiroWilk test. For continuous variables, the data were presented as means with $95 \%$ confidence interval $(95 \% \mathrm{CI})$ while categorical variables were presented as a sample percentage (\%). The MNA tool was validated by calculating Spearman's rank correlation coefficients between the overall MNA score and each of the 18 items included in the MNA. BMI has been found to be a useful tool in clinical and public health practice for assessing the nutritional status of adults [6] and the elderly [8]. The prevalence of three nutritional categories-malnourishment, risk of malnourishment and normal nutritional statuswere calculated to assess the respondents' nutritional status. The odds ratios (ORs) and 95\% confidence intervals (95\% CIs) were calculated. The significance of ORs was assessed by Wald's statistics. The levels of statistical significance were set at $\mathrm{P}<0.05\left(^{*}\right)$, $\mathrm{P}<0.01$ (**), $\mathrm{P}<0.001{ }^{(* * *)}$. The Shapiro-Wilk test was used to test the normality of distributions. The average nutritional status of groups was compared by ANOVA, and frequency distributions were evaluated by Pearson's chi-squared $\left(\chi^{2}\right)$ test. Two-tailed p-values $<0.05$ were considered statistically significant in all tests. Analyses were performed using Statistica software (version 13.1 PL; StatSoft Inc., Tulsa, OK, USA; StatSoft, Krakow, Poland).

\section{RESULTS}

The participants were $37.9 \%$ male and $62.1 \%$ female (Table 1) with a mean age of 70.6 years (minimum 65 years, maximum 88 years). Only urban residents lived in nursing homes, including 15 men and 24 women. Independently living seniors were more often female $(19.0 \%)$ urban dwellers ( $p=0.0023)$, and only $8.6 \%$ of male respondents lived alone. Regardless of their place of residence, the majority of respondents lived with at least one family member, usually a spouse or children.

Table 1. Characteristic features of the surveyed population

\begin{tabular}{|c|c|c|}
\hline Characteristic features & $\begin{array}{c}\text { Number } \\
\text { of respondents } \\
\mathrm{n}(\%)\end{array}$ & $\mathrm{p}$-Value \\
\cline { 1 - 2 } Female & $247(62.1)$ & \multirow{2}{*}{$<0.05$} \\
\hline Male & $151(37.9)$ & \\
\hline
\end{tabular}

\begin{tabular}{|c|c|c|}
\hline \multicolumn{3}{|c|}{ Place of residence } \\
\hline Rural area & $142(35.7)$ & \multirow{2}{*}{$<0.05$} \\
\hline Urban area & $256(64.3)$ & \\
\hline \multicolumn{2}{|c|}{ Residential environment } \\
\hline Living with family & $299(75.1)$ & \multirow{2}{*}{$<0.01$} \\
\hline Living independently & $60(15.1)$ & \\
\cline { 1 - 2 } Living in a nursing home & $39(9.8)$ & \\
\hline \multicolumn{2}{|c|}{ Chronic diseases } \\
\hline
\end{tabular}

\begin{tabular}{|c|c|c|}
\hline $\begin{array}{c}\text { Hypertension \& } \\
\text { cardiovascular diseases }\end{array}$ & $109(27.4)$ & \multirow{5}{*}{$<0.05$} \\
\hline Diabetes & $57(14.3)$ & \\
\hline Osteoporosis & $29(7.3)$ & \\
\hline Asthma/allergy & $21(5.3)$ & \\
\hline Other & $182(45.7)$ & \\
\hline \multicolumn{3}{|c|}{ Nutritional status } \\
\hline Overweight/obese & $58(14.6)$ & \multirow{3}{*}{$<0.01$} \\
\hline Healthy weight & $95(23.9)$ & \\
\hline Risk of malnutrition & $247(61.5)$ & \\
\hline
\end{tabular}

The respondents' nutritional status was evaluated based on a BMI scale designed specifically for the elderly. There are no evidence-based guidelines to assist clinicians in classifying elderly patients based on their BMI values. However, there is strong emerging evidence that BMI cut-offs may not be appropriate in seniors. Therefore, it is recommended that BMI 
classifications are adjusted for people aged $\geq 65$ years as follows: underweight $\leq 23.99 \mathrm{~kg} / \mathrm{m}^{2}$, healthy weight $24-29.99 \mathrm{~kg} / \mathrm{m}^{2}$ and overweight $>30 \mathrm{~kg} / \mathrm{m}^{2}[5,31]$.

The BMI values of most respondents were indicative or malnutrition or risk of malnutrition, regardless of gender (mean BMI $23.88 \mathrm{~kg} / \mathrm{m}^{2} \pm 5.08$ ) (Figure 1). Most overweight and obese respondents were female $(\mathrm{p}=0.0001)$. The obtained scores were not differentiated by the respondents' place of residence or residential environment. A significantly $(\mathrm{p}=0.0012)$ higher number of respondents with healthy weight were urban dwellers who lived with their family or spouse. Gender was not a differentiating factor.

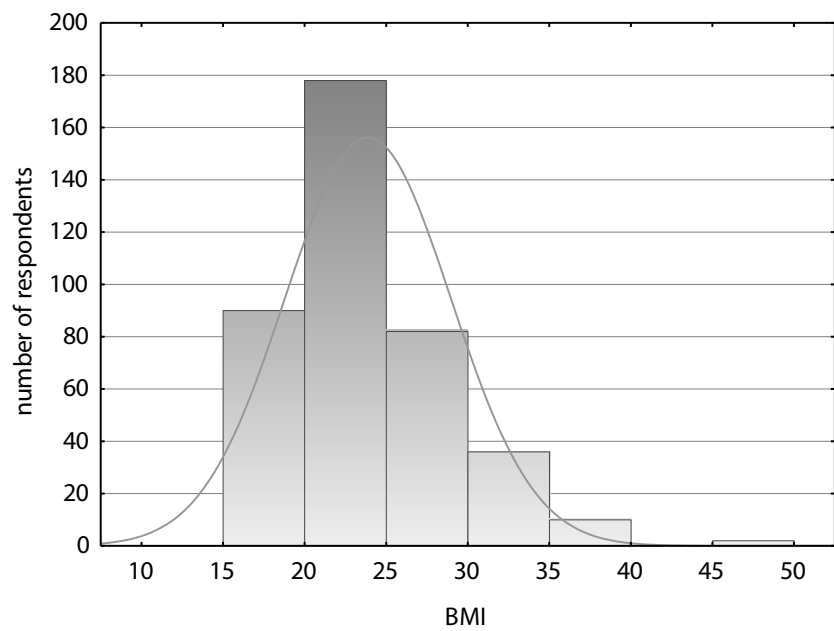

Figure 1. Evaluation of nutritional status based on BMI values, normal distribution
The respondents' BMI values were influenced by lifestyle and diet (Table 2). Patients whose food intake decreased significantly in the previous three months were characterized by a decrease in BMI values (mean BMI of $20.90 \mathrm{~kg} / \mathrm{m}^{2}, \mathrm{p}<0.0001$ ). Respondents whose body weight decreased by more than $3 \mathrm{~kg}$ in the previous 3 months were also characterized by lower BMI (mean BMI of $22.25 \mathrm{~kg} / \mathrm{m}^{2}, \mathrm{p}<0.0001$ ). The observed decreased BMI values was significantly $\left(p=0.0012 ; r_{s}=0.6714\right)$ correlated with lower food intake. Unintentional weight loss greater than $3 \mathrm{~kg}$ was most frequently noted in respondents living in nursing homes and living independently $(\mathrm{p}=0.0021)$. Eating difficulties also considerably influenced the respondents' nutritional status. Respondents who required assistance in eating where characterized by lower BMI (mean BMI of $20.95 \mathrm{~kg} / \mathrm{m}^{2}, \mathrm{p}=0.0054$ ), and these seniors were significantly $(\mathrm{p}=0.0001)$ less likely to live with their families. Appetite did not exert a significant influence on BMI ( $p=0.1411)$.

The surveyed respondents suffered from chronic diseases. Their BMI values were most influenced by colorectal cancer (mean BMI of $18.10 \mathrm{~kg} / \mathrm{m}^{2}$ ) and ischemic heart disease (mean BMI of $20.63 \mathrm{~kg} / \mathrm{m}^{2}$ ). The BMI of respondents with diabetes was significantly higher $\left(24.98 \mathrm{~kg} / \mathrm{m}^{2}, \mathrm{p}=0.0016\right)$. In elderly patients suffering from chronic diseases, pharmacological treatment can adversely influence nutritional status; however, these factors were not significantly correlated in the surveyed subjects $(\mathrm{p}=0.2627)$.

Table 2. Distribution of BMI values and the number of points in the MNA test depending on the characteristics of the population

\begin{tabular}{|c|c|c|c|c|c|}
\hline \multirow{2}{*}{ Parameter } & \multicolumn{3}{|c|}{ BMI [kg/m2] } & \multirow{2}{*}{$\begin{array}{c}\text { Points in MNA } \\
\text { test }\end{array}$} & \multirow{2}{*}{ p-Value } \\
\hline & Mean/S & Minimum & Maximum & & \\
\hline \multicolumn{5}{|c|}{ Sex } & $*$ \\
\hline Female & $25.61 \pm 3.7$ & 18.6 & 45.1 & 22.6 & \\
\hline Male & $22.41 \pm 5.9$ & 17.4 & 46.3 & 19.5 & \\
\hline \multicolumn{5}{|c|}{ Residential environment } & $* *$ \\
\hline living with family & $23.9 \pm 2.4$ & 18.7 & 46.3 & 23.3 & \\
\hline living independently & $24.99 \pm 3.1$ & 18.9 & 35.2 & 21.7 & \\
\hline living in nursing home & $21.48 \pm 5.4$ & 17.4 & 21.7 & 18.6 & \\
\hline \multicolumn{5}{|c|}{ Nutritional status } & ns \\
\hline overweight/obese & $34.7 \pm 4.9$ & 30.0 & 46.3 & 23.9 & \\
\hline healthy weight & $26.4 \pm 2.6$ & 24.2 & 29.9 & 23.1 & \\
\hline underweight & $20.8 \pm 2.1$ & 17.4 & 23.1 & 18.5 & $*$ \\
\hline $\begin{array}{l}\text { unintentional weight loss } \\
\text { during the last } 3 \text { months }\end{array}$ & $23.54 \pm 2.9$ & 19.0 & 33.6 & 19.4 & $* *$ \\
\hline $\begin{array}{l}\text { psychological stress in the past } \\
3 \text { months }\end{array}$ & $24.3 \pm 5.1$ & 18.3 & 38.5 & 16.2 & $* * *$ \\
\hline
\end{tabular}

Nutritional status BMI categorized with cut-offs according to: underweight BMI $<23.99 \mathrm{~kg} / \mathrm{m}^{2}$; healthy weight BMI = 24.0 to $29.9 \mathrm{~kg} / \mathrm{m}^{2}$; overweight/obesity $\mathrm{BMI} \geq 30 \mathrm{~kg} / \mathrm{m}^{2}$,

Statistically significant at $* p<0.05 ; * * \mathrm{p}<0.01, * * * \mathrm{p}<0.001$, ns - not significant. 
Motor skills were significantly $(p=0.0052)$ correlated with BMI values. The majority of respondents did not have mobility problems $(73.6 \%)$ and were characterized by the highest BMI (mean BMI of $24.30 \mathrm{~kg} / \mathrm{m}^{2}$ ). Bedridden patients accounted for $4.88 \%$ of the studied population, and they were characterized by the lowest BMI $\left(21.54 \mathrm{~kg} / \mathrm{m}^{2}\right)$ which was significantly correlated with lower food intake $(p=0.0002)$. The place of residence significantly influenced the respondents' nutritional status. Rural residents were characterized by significantly $(\mathrm{p}<0.0001)$ lower BMI $\left(21.19 \mathrm{~kg} / \mathrm{m}^{2} \pm 4.12\right)$ than urban dwellers $\left(25.34 \mathrm{~kg} / \mathrm{m}^{2} \pm 4.76\right)$.

The respondents' BMI values were significantly correlated $(p<0.0001)$ with their MNA scores (Figure 2). The average MNA score was 21.0 \pm 4.4 . A strong positive $\left(r_{s}=0.7293\right)$ correlation was observed in Spearman's rank correlation test, indicating that a decrease in BMI values was correlated with a decrease in MNA scores. fruit and vegetables less than once a week were at greater risk of malnutrition. These respondents were significantly more often residents of nursing homes or independently living seniors $(p=0.0002)$ who had a sedentary lifestyle $(\mathrm{p}=0.034)$, experienced pain $(p=0.0001)$ and eating difficulties $(p=0.0023)$. Dairy products and meat were the most popular foods in the surveyed population, whereas legumes, fish and vegetables were least popular. A strong negative $\left(r_{\mathrm{s}}=\right.$ -0.863 ) correlation between a sedentary lifestyle and the deficiency of nutritional foods in the respondents' diets was observed in Spearman's rank correlation test. In the studied population, $75 \%$ of the respondents, including patients with a history of hospitalization, had never been subjected to nutritional assessments. The respondents who had been assessed with the use of various questionnaires suffered from colorectal and pancreatic cancer, and they had been evaluated as part of their oncological treatment. In this group, 2/3 of the respondents had been assessed with the use of the

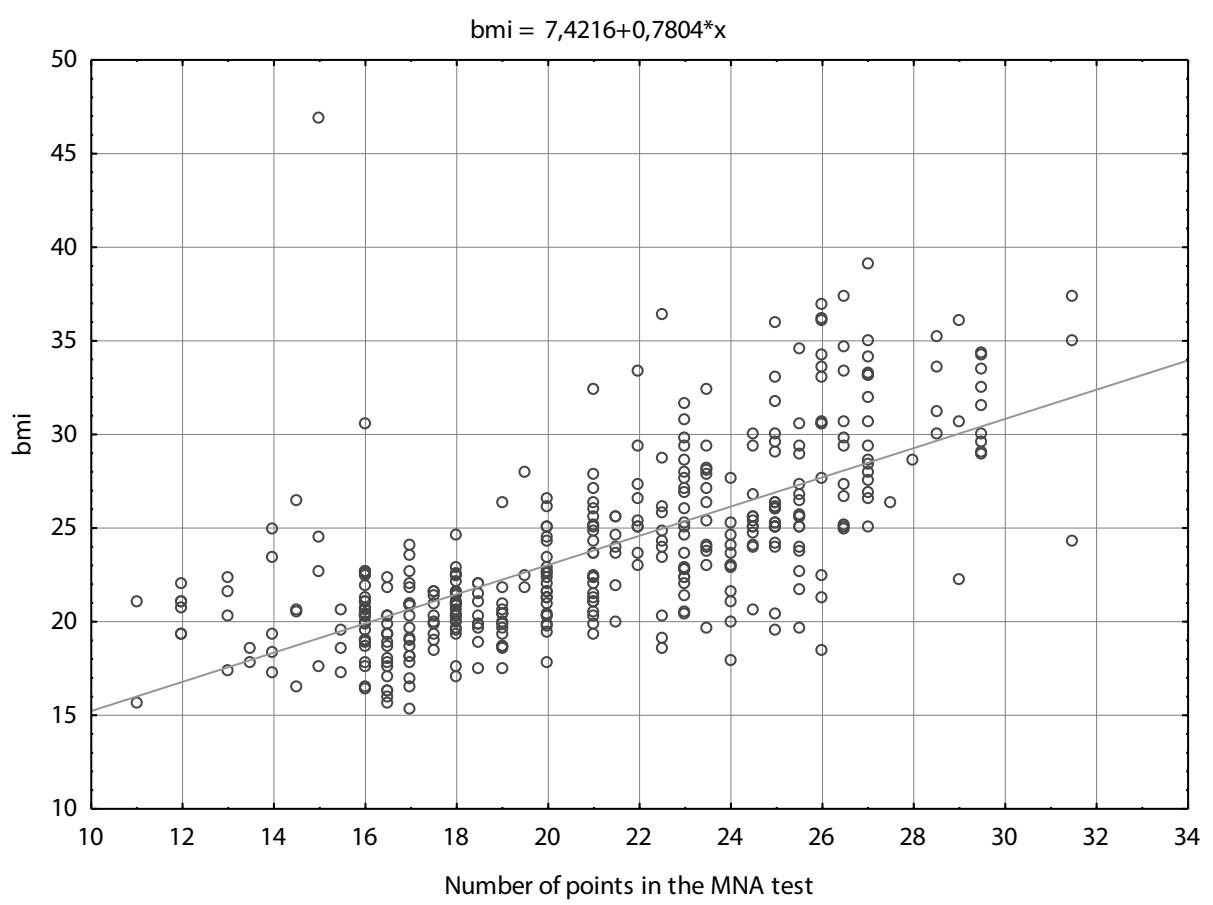

Figure 2. Correlation between MNA scores and BMI values in relation to nutritional status

The respondents' physical activity levels were correlated with their overall MNA scores, and persons with a sedentary lifestyle scored a significantly lower number of points in the MNA test $(p<0.05)$. Respondents receiving more than 3 medications daily were characterized by lower MNA scores $(p<0.05)$ and a higher risk of malnutrition.

The respondents' dietary preferences were also significantly correlated with malnutrition or the risk of malnutrition expressed by their MNA scores. People who consumed dairy products, legumes, meat, fish,
MNA tool, and the nutritional status of the remaining subjects had been diagnosed with custom-designed questionnaires or the SGA tool. Only 11 patients had been assessed more than once, and the remaining patients who had been diagnosed as malnourished or at risk of malnutrition had not been evaluated repeatedly.

Based on the results of anthropometric analyses, the studied population was divided into three groups: a) overweight/obese, b) at risk of malnutrition/ malnourished, c) healthy weight (reference group). The presence of relationships between the risk of 
malnutrition and overweight vs. health condition, nutritional status and, indirectly, the score in the MNA screening test was determined (Table 3 ). by significantly lower MNA scores $(\mathrm{p}<0.05)$. Spearman's rank correlation test revealed a strong negative correlation $\left(r_{\mathrm{s}}=-0.841\right)$ between the above

Table 3. Odds ratio (95\% confidence interval). Relationships between malnutrition or excess body weight and factors influencing the score in the MNA questionnaire

\begin{tabular}{|c|c|c|}
\hline & $\begin{array}{c}\text { Overweight/obese (healthy } \\
\text { weight reference group) }\end{array}$ & $\begin{array}{c}\text { Risk of malnutrition (healthy } \\
\text { weight reference group) }\end{array}$ \\
\hline Weight loss in the last 3 months & $0.94(0.87-1.03)$ & $1.73^{* *}(1.54-1.89)$ \\
\hline Neuropsychological problems & $0.93(0.71-1.04)$ & $1.09(0.94-1.21)$ \\
\hline Takes more than 3 prescription drugs per day & $1.06(0.91-1.19)$ & $1.06(0.89-1.07)$ \\
\hline Pressure sores or skin ulcers & $1.04(0.82-1.15)$ & $1.29 *(1.19-1.59)$ \\
\hline Number of full meals eaten daily & $1.87 *(1.32-2.06)$ & $0.78^{*}(0.66-1.03)$ \\
\hline Consumptions markers for protein intake & $1.13(0.88-1.24)$ & $1.35^{*}(1.21-1.57)$ \\
\hline Views self as being malnourished & $1.09(0.94-1.23)$ & $0.69^{* *}(0.52-0.89)$ \\
\hline Views self as having no nutritional problems & $2.06^{* * *}(1.57-2.34)$ & \\
\hline
\end{tabular}

Statistically significant at $* p<0.05 ; * * p<0.01 ; * * * p<0.001$;

Unintentional weight loss $(\mathrm{OR}=1.73 ; 95 \%$ CI: $1.54-1.89 ; p<0.01)$ and pressure sores or skin ulcers $(\mathrm{OR}=1.29 ; 95 \%$ CI: $1.19-1.59 ; p<0.05)$ were significantly more prevalent in respondents who were classified as malnourished or at risk of malnutrition, which, combined with a low intake of protein products, can compromise motor skills and the quality of life. Overweight and obese respondents were more likely to consume at least three meals daily $(\mathrm{OR}=1.87 ; 95 \%$ CI: 1.32-2.06; $p<0.001)$. The study demonstrated that other-than-normal nutritional status was significantly more likely to contribute to negative self-perceptions of health and dietary problems.

\section{DISCUSSION}

According to epidemiological data, the prevalence of malnutrition reaches $30-65 \%$ among hospitalized seniors and $25-60 \%$ among residents of nursing homes. Malnutrition is least prevalent (2-32\%) among elderly persons who live with their families [20]. In the present study, the residential environment was significantly correlated with BMI values $(\mathrm{p}=0.0014)$. All nursing home residents were malnourished or at risk of malnutrition, and their BMI values ranged from 18.24 to $22.88 \mathrm{~kg} / \mathrm{m}^{2}$ (mean BMI $21.49 \mathrm{~kg} / \mathrm{m}^{2} \pm 2.95$ vs. $\mathrm{BMI}=23.94$ in respondents living with families and $\mathrm{BMI}=24.99 \mathrm{~kg} / \mathrm{m}^{2}$ in independently living seniors). The WOBASZ Senior study conducted with the use of an abridged MNA questionnaire revealed that $13 \%$ of Polish seniors were malnourished and $57 \%$ were at risk of malnutrition [30].

Many chronically ill seniors suffer from depression and chronic pain, which decreases their wellbeing and quality of life. The respondents affected by psychological stress and disease were characterized factors. Ahmadi et al.[2] demonstrated the depression had a negative impact on the nutritional status of seniors assessed with the use of the Mini-MNA questionnaire $(\mathrm{r}=-0.58, \mathrm{p}<0.0001)$. Residents of large urban areas were also at significantly more susceptible to depression than rural inhabitants $(39.5 \%$ vs. $3.9 \%)$ [2]. Similar results were reported in an Israeli study where malnourished seniors were more likely to be depressed and physically inactive [13].

Depression in the elderly can often lead to malnutrition or dehydration, which, in turn, can induce various kinds of physical illnesses. Physical ailments, including those associated with malnutrition, can also induce depression in the elderly who are more psychologically vulnerable [27]. Senior citizens should receive psychiatric and nutritional assistance due to the strong relationship between the body and the mind in older age.

Lack or loss of appetite contributes to the risk of malnutrition. Payett et al. [21] demonstrated that healthy appetite increases energy intake $(p<0.01)$ and protein intake $(\mathrm{p}<0.05)$. In a study by Shahar [26] more than $20 \%$ of the respondents suffered from poor appetite, and these patients were diagnosed as malnourished. In the current study, appetite was significantly correlated with the MNA score $(p<0.05)$, and a strong positive correlation $\left(\mathrm{r}_{\mathrm{s}}=0.7854\right)$ was noted in Spearman's rank correlation test. The average MNA score of respondents with normal appetite was $22.7 \pm 3.3$, and it was higher than the MNA score of patients who suffered from lack of appetite or whose appetite had deteriorated significantly in the 3 preceding months $(20.8 \pm 2.7)$. Loss of appetite is highly implicated in unintentional weight loss and malnutrition. Similar observations were made by Brabcova in a study of seniors residing in the Czech 
region of Budejovice, where unintentional weight loss, depression and decreased appetite were most highly correlated with malnutrition. Social and economic factors were less implicated in malnutrition than biological factors [7].

The taste and aroma of food stimulate appetite and contribute to the pleasure of eating. In this study, respondents with an impaired sense of taste and smell were characterized by significantly lower MNA scores (21.0 v 22.7 in respondents without such impairment; $p=0.0023$ ). Many pharmaceutical treatments can alter perceptions of taste and smell, including lipid lowering drugs, antihistamines, antibiotics, antiinflammatory drugs, bronchodilators and other asthma drugs, antihypertensive drugs, Parkinson's disease treatments and antidepressants. The mechanism by which these drugs affect taste or smell remains unknown [11]. Eating difficulties associated with oral health problems, limited motor ability and digestive disorders contributed to malnutrition $(\mathrm{p}=0.0012)$. Research indicates that chewing problems can decrease food intake and increase the risk of malnutrition [13].

In the present study, the respondents' subjective evaluations of health status were significantly correlated with their MNA scores $(\mathrm{p}=0.0012)$. Persons who described their health status as good and very good, relative to their peers, scored a higher number of points in the MNA test $(\mathrm{p}<0.05)$, and most of them were women living with their families or living independently. Respondents who described their health status as poor or very poor, relative to their peers, scored significantly fewer points in the MNA test $(\mathrm{p}<0.05)$, and most of them were independently living men and women residing in nursing homes.

When the risk of malnutrition is diagnosed early in senior citizens, nutritional interventions can be introduced to increase energy and protein intake and, consequently, prevent nutrition-related diseases. According to ESPEN data, malnutrition can decrease physical activity, impair rehabilitation, prolong treatment and hospitalization of the elderly [24]. Late diagnosis of malnourished patients with protein and energy deficiencies and sarcopenia prolongs hospitalization and increases treatment costs [4]. The MNA tool supports rapid and simple evaluations of nutritional status without increasing treatment costs. The presented method is sensitive, it does not require specialist tests, it effectively diagnoses patients who are at risk of malnutrition, and it supports quick nutritional interventions, in particular in health care facilities [25].

\section{Strengths and Limitations}

The strength of the study was the anthropometric assessment and assessment of the nutritional status of a large group of elderly people living in various environments. Measurements of height, weight and weight, calf circumference (CC), and mid-arm circumference (MAC) were made using validated equipment. An additional strength was the research using the MNA questionnaire, many people were assessed for the first time and thus diagnosed with the risk of malnutrition.

The limitation in the study was the difficulty in reaching people living alone, and this group is definitely more at risk of malnutrition than people living with their family.

\section{CONCLUSIONS}

1. The BMI values and MNA scores of the tested subjects indicate that the majority of the surveyed respondents were malnourished or at risk of malnutrition, regardless of gender.

2. In the studied population, the risk of malnutrition was not significantly correlated with the respondents' economic status.

3. Unintentional weight loss, depression, chronic pain and decrease in appetite were the main factors that contributed to malnutrition in seniors.

4. In the present study, the residential environment significantly influenced the patients' nutritional status, in particular in respondents with impaired motor abilities and eating difficulties.

5. The MNA questionnaire is a simple and sensitive tool which should be used to evaluate all patients older than 65 years in outpatient clinics, hospitals, nursing homes and sanatoriums.

6. Assessment of the nutritional status of the elderly should be included in screening tests carried out in primary health care facilities, in dietitian offices or in other medical facilities.

\section{Acknowledgments}

The authors would like to thank all participants who contributed to this study and assisted in body composition measurements: Joanna Kostecka, Marta Myszkowska, Agnieszka Korzeniowska and Monika Jankowska.

\section{Conflict of interest}

The authors declare no conflict of interest.

\section{REFERENCES}

1. Aeberhard C., Stanga Z., Leuenberger M.: Practical scores for the detection of malnutrition. Ther Umsch 2014; 71(3):141-147. doi: 10.1024/0040-5930/ a000495.

2. Ahmadi S.M., Mohammadi M.R., Mostafavi S.A., Keshavarzi S., Kooshesh S.M., Joulaei H., Sarikhani Y., Peimani P., Heydari S.T., Lankarani 
K.B.: Dependence of the geriatric depression on nutritional status and anthropometric indices in elderly population. 2013;8(2):92-96.

3. Alzahrani S.H., Alamri S.H.: Prevalence of malnutrition and associated factors among hospitalized elderly patients in King Abdulaziz University Hospital, Jeddah, Saudi Arabia. BMC Geriatr 2017;17(1):136. doi: 10.1186/s12877-017-0527-z

4. Antunes A.C., Araújo D.A., Veríssimo M.T., Amaral T.F.: Sarcopenia and hospitalisation costs in older adults: a cross-sectional study. Nutr Diet 2017;74(1):46-50. doi: 10.1111/1747-0080.12287.

5. Australian and New Zealand Society for Geriatric Medicine. 2011. Position Statement No 19, Obesity and the older person. http://www.anzsgm.org/documents/ ObesityandtheOlderPerson11Sept113.pdf

6. Bailey K.V., Ferro-Luzzi A.: Use of body mass index of adults in assessing individual and community nutritional status. Bull World Health Organ 1995;73(5):673-680.

7. Brabcová $I_{.}$, Trešlová $M_{.}$. Bártlová $S_{.}$Vacková $J_{.}$, Tóthová $V_{.}$, Motlová L.: Risk factors for malnutrition in seniors aged $75+$ living in home environment in selected regions of the Czech Republic. Cent Eur J Public Health. 2016;24(3):206-210. doi: 10.21101/cejph. a4283.

8. Charlton K.E., Kolbe-Alexander T.L., Nel J.H.: Development of a novel nutrition screening tool for use in elderly South Africans. Pub Health Nutrition 2005;8(05):468-479.

9. Dey D.K., Rothenberg E., Sundh V., Bosaeus I., Steen B.: Body Mass Index, weight change and mortality in the elderly. A 15 year longitudinal population study of 70 y olds. Eur J Clin Nutr 2001;55:482-492.

10.Duda G.: Samotność jako czynnik zaburzeń odżywiania seniorów. w: Przeciw samotności, pod red. J. Twardowskiej-Rajewskiej. Wydawnictwo. Naukowe UAM, Poznań:2005.

11. Duffy V.B., Backstrand J.R., Ferris A.M.: Olfactory dysfunction and related nutritional risk in free-living, elderly women. J Am Diet Assoc 1995;95(8):879-884.

12.Elia M., Stratton R.J.: An analytic appraisal of nutrition screening tools supported by orginal data with particular reference to age. Nutrition 2012;28:477-494.

13. Feldblum I., German L., Castel H., Harman-Boehm I., Bilenko N., Eisinger M., Fraser D., Shahar D.R.: Characteristics of undernourished older medical patients and the identification of predictors for undernutrition status. Nutr J 2007;6:37. doi.org/10.1186/1475-2891-637.

14.Ferguson M., Banks M., Bauer J., Isenring E., Vivanti A., Capra S.: Nutrition screening practices in Australian healthcare facilities: a decade later. Nutr Diet 2010;67:213-218.

15. Guigoz Y.V.B., Garry P.J.: Mini Nutritional Assessment: a practical tool for grading the nutritional state of the elderly patients. Facts Res Gerontol 1994;2:15-60.

16. Guigoz Y.: The Mini Nutritional Assessment (MNA) review of the literature--What does it tell us? J Nutr Health Aging 2006;10:466-85.
17. Kaiser R., Winning K., Uter W., Stehle P., Lesser S., Sieber C.C., Bauer J.M.: Comparison of two different approaches for the application of the Mini Nutritional Assessment in nursing homes: resident interviews versus assessment by nursing staff. J Nutr Health Aging 2009;13(10): 863-869. doi: 10.1007/s12603-009-0243-2.

18. Kondrup J., Allison S.P., Elia M., Vellas B., Plauth M.: ESPEN Guidelines for Nutrition Screening 2002. Clin Nutr 2003;22(4):415-421

19. Mastronuzzi T., Grattagliano I.: Nutrition as a Health Determinant in Elderly Patients. Curr Med Chem 2019;26(19):3652-3661. doi: 10.2174/ 092986732466670523125806.

20.Mziray M., Żuralska R., Książek J., Domagała P.: Malnutrition among the elderly, the methods of assessment, prevention and treatment. Ann Acad Med Gedan 2016;46: 95-105.

21. Payette H, Gray-Donald K, Cyr R, Boutier V.: Predictors of dietary intake in a functionally dependent elderly population in the community. V Am J Public Health 1995;85(5):677-683.

22.Pichard C., Kyle U.G., Morabia A., Perrier A., Vermeulen B., Unger P.: Nutritional assessment: lean body mass depletion at hospital admission is associated with an increased length of stay. Am J Clin Nutr 2004;79(4):613-618.

23.Ramic E., Pranjic N., Batic-Mujanovic O., Karic E., Alibasic E., Alic A.: The effect of loneliness on malnutrition in elderly population. Med. Arh 2011;65(2):92.

24.Sánchez-Rodríguez $\quad D ., \quad$ Marco $\quad E$. . Annweiler C., Ronquillo-Moreno $N$. ., Tortosa A., VázquezIbar O., Escalada J.M.: Malnutrition in postacute geriatric care: Basic ESPEN diagnosis and etiology based diagnoses analyzed by length of stay, in-hospital mortality, and functional rehabilitation indexes. Arch Gerontol Geriatr. 2017;73:169-176. doi: 10.1016/j. archger.2017.07.010.

25.Schrader E, Grosch E., Bertsch T., Sieber C.C., Volkert D.: Nutritional and Functional Status in Geriatric Day Hospital Patients - MNA Short Form Versus Full MNA. J Nutr Health Aging. 2016;20(9):918-926. doi: 10.1007/ s12603-016-0691-4.

26. Shahar D., Shai I., Vardi H., Fraser D.: Dietary intake and eating patterns of elderly people in Israel: who is at nutritional risk? Eur J Clin Nutr 2003;57(1):18-25. doi: 10.1038/sj.ejcn.1601523.

27. Singh D.K., Manaf Z.A., Yusoff N.A., Muhammad N.A., Phan M.F., Shahar S.: Correlation between nutritional status and comprehensive physical performance measures among older adults with undernourishment in residential institutions. Clin Interv Aging 2014;9:14151423. doi: 10.2147/CIA.S64997.

28.Sorensen J., Kondrup J., Prokopowicz J., Schiesser M., Krahenbuhl L., Meier R., Liberda M.: EuroOOPS: an international, multicentre study to implement nutritional risk screening and evaluate clinical outcome. Clin Nutr 2008;27:340-349. 
29. Sullivan D.H., Morley J.E., Johnson L.E., Barber A., Olson J.S., Stevens M.R., Yamashita B.D., Reinhart S.P., Trotter J.P., Olave X.E.: The GAIN (Geriatric Anorexia Nutrition) registry: the impact of appetite and weight on mortality in a long-term care population. $J$ Nutr Health Aging 2002;6(4):275-81.

30. Waśkiewicz A., Sygnowska E., Broda G.: Ocena stanu zdrowia i odżywienia osób w wieku powyżej 75 lat w populacji polskiej. Badanie Wobasz-Senior. Brom Chem Toksykol 2012;(3):614-618.

31. Winter J.E., MacInnis R.J., Wattanapenpaiboon N., Nowson C.A.: BMI and all-cause mortality in older adults: a meta-analysis. Am J Clin Nutr. 2014;99(4):875890. doi: 10.3945/ajcn.113.068122.

32. Wojszel Z.B.: Niedożywienie i dylematy leczenia żywieniowego w geriatrii. Post Nauk Med 2011; 24(8):649.

33. World Population to Exceed 9 Billion by 2050. United Nations Population Division/DESA), New York 2009.

Received: 27.04.2021

Accepted: 30.05.2021 